\title{
ТРАВЕСТУВАННЯ ЖАНРУ ЧЕРЕЗ ЗАГОЛОВОК У "ДИЯБОЛІЧНИХ ПАРАБОЛАХ" ПОРФИРІЯ ГОРОТАКА
}

\author{
Інна ВОЛКОВИНСЬКА
}

\author{
Кандидат філологічних наук, старший викладач, \\ Кам'янець-Подільський національний університет імені Івана Огієнка, УКРАЇНА
}

\section{DOI 10.25128/2304-1222.19.48.01}

The article deal s with the problem of correl ation of title and genre of a text The research field includes headlines with a nomination of a particular genre. The subject of research are the texts of the collection "The Diabolic Parables" of the mystical poet Porphyry Horotak. Functional capabilities of titles with genre nomination, their influence on genre reception are anal yzed. The complicated relations that emerge between the announced genre and the genre features of the text can be divided into three varieties: travestying of the genre, the "adaptation" to the canons of the genre, and the relations that come close to equival ence. Method of travestying of the genre is real ized by parodying and remaking the genre canon. This leads to forming of a particular genre simulacrum "Adaptation" to the canons of the genre is embodied through ironic pathos, the use of elements of low stylein "high" works. Equival ent links between a title containing a genre nomination and a text are rare. This is due to the belonging of the texts of the collection to literary hoax, which facilitates semantic multilayers. In "The Diabolic Parables" the mystified author brings into thetitlethe following nominations of such genres as fugue, ode, elegy, ballad, song, mystery. The intentional inconsistency between grand content and its formal transvestying is intended to convey to the reader the basic semantic dominants of the collection of texts - depicting of mismatch between the mundane, "low" real ity and the high, romantic ideals of thelyrical hero.

Key words: genre, genre mode, genre canon, titlefinal complex, literary hoax, travestying, Porphyry Horotak.

Стаття присвячена проблемі співвідношення заголовка і жанру твору. У поле дослідження потрапляють заголовки з номінацією певного жанру. Предметом розгляду слугують тексти збірки "Дияболічні параболи" містифікованого поета Порфирія Горотака. Проаналізовано функціональні можливості заголовків із номінацією жанру, їхній вплив на рецепцію жанру. Ускладнені зв'язки, що виникають між анонсованим жанром і жанровими рисами твору, можна поділити на три різновиди: травестування жанру, "пристосування" до канонів жанру і взаємозв’язки, що наближаються до еквівалентності. Прийом травестування жанру реалізується шляхом пародіювання і перелицювання жанрового канону. Це призводить до утворення своєрідного жанрового симулякру. "Пристосування" до канонів жанру втілюється через іронічний пафос, застосування елементів низького стилю у "високих" творах. Еквівалентні зв'язки між заголовком, що містить номінацію жанру, і текстом явище рідкісне. Це пояснюється приналежністю текстів збірки до літературної містифікації, яка сприяє смисловій багатошаровості. У "Дияболічних параболах" містифікований автор залучає до заголовків номінації таких жанрів як фуга, ода, елегія, балада, пісня, містерія. Зумисна неузгодженість між піднесеним змістом і його 
формальним травестуванням покликана донести до читача основні смислові домінанти збірки - змалювання невідповідності між приземленою, "низькою" дійсністю та високими, романтичними ідеалами ліричного героя.

Ключові слова: жанр, жанрова модель, жанровий канон, заголовково-фінальний комплекс, літературна містифікація, травестування, Порфирій Горотак.

Artykuł dotyczy problemu korelacji tytułu i gatunku utworu. Obszar badań obejmuje nagłówki z nominacją określonego gatunku. Przedmiotem rozważań są teksty ze zbiórki „Paraboły diaboliczne” mistycznego poety Porfirego Horotaka. Analizowana jest funkcjonalność tytułów z nominacją gatunku i ich wpływ na jego odbiór. Skomplikowane relacje, które pojawiają się między zapowiedzianym gatunkiem a cechami gatunkowymi utworu, można podzielić na trzy odmiany: trawestacja gatunku, „adaptacja” do kanonów gatunku i związek zbliżony do równoważności. Akceptacja trawestacji gatunku real izowana jest przez parodiowanie i przelicowanie kanonu gatunku. Prowadzi to do powstania pewnego rodzaju symulakru gatunkowego. „A daptacja” do kanonów gatunku ucieleśnia ironiczny patos, wykorzystanie elementów o niskim stylu w dziełach „wysokich”. Równoważne powiązania między tytułem zawierającym nominację gatunku a tekstem są rzadkie. Wynika to z przynależności tekstów zbioru do mistyfíkacji literackiej, która promuje semantyczną wielowarstwowość. W „Parabołach diabolicznych" tajemniczy autor czerpie z tytułów nominacje takich gatunków jak fuga, oda, elegia, ballada, piosenka, tajemnica. Umyślna niespójność między wysublimowaną treścią a jej formalną trawestacją ma na celu przekazanie czytelnikowi podstawowej semantycznej dominanty zbioru - przedstawienia nieodpowiedniości między przyziemną, „niską” rzeczywistością a wysokimi, romantycznymi ideałami lirycznego bohatera.

Słowa kluczowe: gatunek, model gatunku, kanon gatunku, kompleks tytułowo-finałowy, mistyfikacja literacka, trawestacja, Porfiry Horotak.

Смислоутворювальні можливості заголовка, його зв'язок з тематикою, проблематикою, ключовими образами твору не викликають сумнівів. Проблемі функціональності заголовка в художньому творі присвячено чимало праць зарубіжних і вітчизняних дослідників (3. Блісковського [Блисковский 1972], І. Арнольд [Арнольд 1978], Н. Кожиної [Кожина 1988], Л. Грицюк [Грицюк 1992], С. Кржижановського [Кржижановский 2001], С. Іванової [Иванова 2006], В. Мержвинського [Мержвинський 2007], С. Рижкової [Рижкова 2014] та ін.). Проте, проблематика заголовково-фінального комплексу настільки широка і багатоманітна, що й досі залишається невисвітленим чимало аспектів. Зокрема це стосується проблеми співвідношення заголовка і жанру твору. Актуальність такого дослідження очевидна паратекст (елементом якого є заголовок) та архітекст (пов’язаний із жанровим каноном) є формами інтертекстуального буття тексту, що виводить художній твір у загальнокультурний простір. 
Серед різновидів заголовків привертають увагу ті, у яких присутня номінація певного жанру. Як відомо, заголовок спрямовує очікування читача, формує горизонт його сподівань. Подальше знайомство з текстом твору або підтверджує, або спростовує ці очікування. Вказівка на жанр не просто впливає на горизонт очікувань, а ще залучає читача до уявного витворення моделі твору на основі досвіду.

Заголовками, які містять номінацію жанру, рясніє поетична збірка "Дияболічні параболи" містифікованого Порфирія Горотака. Це - "Астральна фуга", "Лідійська пісня", "Острівна баляда", "Ода до трактора", "Залізобетонна елегія", "Елегія собі", "Індестанський гімн", "Архисонет Юрію Кленові", "Пияцька пісня", "Асирійська ода", "Ляйтенантська містерія". Вже сама назва збірки відсилає читача до жанру параболи й актуалізує основні його ознаки - різноплановість, інакомовність, повчальність. Іронічно-пародійний зміст творів збірки, на перший погляд, контрастує із визначенням жанру, яке налаштовує на філософський чи медитативний текст. Однак між твором і заголовком існують зв'язки еквівалентності, адже пародійність також передбачає різноплановість. Епітет "дияболічні" натякає на гостроту текстів і добре вписується у формат містифікації.

Вказівка на жанр у заголовках поетичних творів Порфирія Горотака виконує специфічну роль - вона не лише спрямовує очікування читача в певне русло, а й часто сприяє обману таких очікувань. Так у творі "Астральна фуга" ${ }^{1}$ [Клен 1992 , 186] номінація жанру фуги орієнтує читача на мелодійність твору та його поліфонічність. Варто зауважити, що художній прийом поліфонії стає знаковим для мистецтва XX століття. О. Іванова, досліджуючи структуру поліфонічної композиції та іiі реалізацію в художньому тексті, зазначає, що "саме у ХX столітті поліфонія відроджується і переживає свій черговий розквіт у музичному мистецтві, одночасно входить і завойовує свої позиції у художньому просторі інших видів мистецтв. <..> явище [поліфонії. - I. B.] стає феноменом багатоголосної культури сучасності" [Иванова 2016: 111]. Дослідниця стверджує, що саме жанр фуги набирає у XX столітті особливої популярності. Р. Біляшевич пояснює стрімкий розвиток поліфоніч-

\footnotetext{
${ }^{1}$ Оскільки Юрій Клен був одним із авторів літературної містифікації "Порфирій Горотак", тут і далі посилання на твори Порфирія Горотака подаються за виданням [Клен 1992].
} 
них форм в українській літературі XX століття впливом барокової традиції і зауважує, що "радянським літераторам не рідко доводилося поєднувати ці вишукані поліфонічні форми з далеко не такими ж якісними змістами. Тут уже домінували не смак і майстерність, а диктат ідеології та інстинкт самозбереження" (Біляшевич 2013, 274). Крізь призму цієї досить слушної тези Р. Біляшевич відчитуємо причини звернення до музичних форм у текстах Порфирія Горотака. Автори містифікації таким чином не лише підкреслювали популярність музичних прийомів у літературі, але й з гіркою іронією викривали невідповідність радянської дійсності пропагованим ідеалам. Епітет "астральна", який супроводжує означуване "фуга" у творі Порфирія Горотака, додає заголовку патетичності, натякає на "високий" зміст. На перший погляд, очікування читача задовольняє тверда строфічна форма твору - сонет, який, як відомо, вважається однією із наймелодійніших віршових форм. Однак, прискіпливий читач все ж помітить підступ. Перш за все, привертає увагу рима, яка увінчує останні двовірші сонета - "кров-любов". Завданням такої банальної, навіть стертої рими не було додати творові звучності. Рима навмисно поміщена в сильну позицію тексту, що привертає до неї увагу і вносить у твір нотки іронічності. Іронічність проймає увесь твір і особливо відчувається у таких дисонансних поєднаннях як "рояться духи", "риштування ідеалу", "криваві мрії", "безмір безглибу". Поліфонічність як незмінна ознака фуги також не отримує втілення у творі. Замість різноголосся цілісної теми отримуємо окремі партії, хаотично скомпоновані. Прагнення до висот, заявлене як у заголовку, так і у першому віршорядку, слабшає із різкою переміною топосу - погляд ліричного героя опускається від астрального простору аж до морських глибин. Таким чином, патетика, яка закладена у заголовкові, стає предметом іронії у творі.

Травестування жанру оди відбувається і в поезії "Ода до трактора" [Клен 1992: 190]. Урбаністичні мотиви, техногенні образи, що набувають особливої популярності на зламі XIX-XX століть, зазнають у творі пародіювання. Позірність возвеличення "непереможного" трактора як "многошрубної сили" проглядається через епітетні структури "мертву масу", "глевкого часу", "чорноземні катаракти". Ці промовисті означення викривають хворобливість епохи, вказують на аномальність благоговійного замилування здобутками цивілізації. Абсурдність возвели- 
чення техніки дістає апогею в епітетній структурі "одухотворений бензин". Алюзивний потенціал має структура "побідну расу" - крізь неї проглядають філософські ідеї "пророка" XX ст. Ф. Ніцше. Однак, контекст, яким оточене поняття "раса" ставить під сумнів ії переможність:

$$
\begin{aligned}
& \text { Це в просторінь глевкого часу } \\
& \text { веде нову побідну расу } \\
& \text { одухотворений бензин". }
\end{aligned}
$$

"Одухотворений бензин" як маркер машинізованої реальності домінує над особистістю, перетворює людей на расу, "расу рабів", підкорених "многошрубній силi". Епітетна структура "побідна раса" набирає в контексті поезії рис оксюморона і актуалізує мотив поневолення людини суспільством, у якому особистість постає лише гвинтиком, придатком великого механізму. Образ "многошрубної сили" відкривається у двоплановості - на поверхні знаходиться проекція на центрального персонажа - трактора, якому і присвячена "ода". Глибинний план - змалювання радянської дійсності як величезного механізму, що підпорядковує і "намножує на мертву масу / підойм і тум сталевий чин". Пафос піднесеного возвеличення перетікає у русло гіркого смутку, який особливо проступає у двох останніх строфах. У 3 -й строфі ("Там, де ходили над Уссурі / лише джень-шеню шукачі - / протне він борозни, як мури, / й пшеничне розводнить Міссурі, / Зеленим Клином ідучи") відбувається розширення топосу, що вказує на масштаби можливої катастрофи. У 4-й строфі показовим є множинний образ "Україн" ("А потім впнеться в розмежів'я, / в нову кордонність Україн"), який символізує трегедію роз’єднаності нації. Назва "ода" у заголовку спричинює утворення своєрідного жанрового симулякру, покликаного привернути увагу читача до підтексту поезії, заглибитися у міжрядкові глибини твору.

Ще більш прозоро відбувається травестування жанру оди в поезії "Асирійська ода" [Клен 1992: 248] Порфирія Горотака. Замість пафосу возвеличення читач натрапляє на емоційну сповідь ліричного героя, оздоблену риторичними окликами і питаннями (які, навіть, створюють піднесену одичну настроєвість), але тут же приперчену і вульгаризмом "біса-чорта" ("Де дістати в біса-чорта / полотняного па- 
nepy"), який аж ніяк не сприяє високому стилю. Нотки викривального гумору переплітаються зі щирістю і навіть розпачем ліричного героя: "Бо на все наклали та̀бу! / O, покину я ичей табір / і піду в той край далекий, / де панує Гаммурабі, / де літав каліф-лелека. // Бо нема того закону, / щуоб на світі не бувало / чаю і синдетикону, / ані навіть ідеалу...". Привертає увагу в поезії образ вавилонського царя Гаммурабі. Його закони ліричний герой називає "мудрими", час правління Гаммурабі протиставляє теперішньому, в якому немає свободи слова, "ані навіть ідеалу". Проте, історично постать правителя неоднозначна. Закони Гаммурабі грунтувалися не лише на справедливості, а й на кривавій жорстокості. Тому викликає сумніви необхідність піддавати однозначній інтерпретації образ вавілонського правителя, який покликаний відтінити складну епоху терору і Другої світової війни. Промовистою є присвята-звернення на початку твору - "To UNRRA" (до Адміністрації ООН). Вона підкреслює протест авторів містифікації проти будь-якого поневолення.

Ключовим образом, який стає предметом псевдооспівування у поетичному творі "Залізобетонна елегія" [Клен 1992: 192], виступає "богорівний залізобетон". Про фальшивість пафосу свідчить заголовок, у якому дисонансно поєдналися дві різнорідні ознаки - важкість, утилітарність залізобетону і легкість, тонка мелодійність і піднесеність елегії. Епітет, який означує елегію ("залізобетонна"), стає визначальним у побудові твору, в доборі лексико-граматичних засобів і фонічному оздобленні вірша. Прикметною є узуальність строфічної організації (катрени), "недбалість" неточних рим ("мурів" - "арматури", "сьогодні" - "безодня", "медаллю" - "ордалій" тощо), лексика із мінімальним зарядом поетичності (до прикладу, у першій строфі: "Розчереплені коробки мурів, / павутиння здерте риштувань / в макабричних сплетах арматури, / $і$ життя затовчене у твань"), алітерації "важких" звуків ("РозчеРеплені коРобки муРів", "в макабРичних сплетах аРматуРи", "над круЖиною / поірЖавленість сталевих трат", "загув бряЖчаннями металю / твого гімну перемоЖний тон"). Проте, завершується поезія нотками медитативності та журливості, притаманними елегії: "Але ось кінець - у грузах муки, доспівався твій гучний псалом... / Ах, які падіння ще й розпуки, принесе нам Сатана-Атом!". Тут звучать профетичні ноти, які натякають на майбутні екологічні катастрофи (н-д, катастрофа на ЧАЕС). Риси заявленого у заголовкові жанру елегії проступають 
саме наприкінці поезії - "оживає" пам’ять жанру (М. Бахтін). Риси елегії - філософічність і мінорність покликані у цьому творі попередити, вберегти людство від катастроф.

Збірка Порфирія Горотака "Дияболічні параболи" наскрізь просякнута мандрівними мотивами. Потяг ліричного героя до мандрівок зумовлений не стільки прагненням до нових знань і пригод (хоч цей чинник також має вагоме значення), скільки бажанням втекти від навколишньої дійсності, яка не дає героєві повної свободи і щастя. Дослідниця містифікації "Порфирій Горотак" Т. Шкарлута якраз у контексті аналізу мотиву мандрів відзначає у збірці ключову опозицію Сходу - Заходу і коментує: "Свропа переважно постає як простір, що морально пригнічує, при цьому екзотичні країни Азії наділені казковим флером фантазії, натхнення, вічної свободи" [Шкарлута 2016: 138]. У творах Порфирія Горотака топоси Сходу та інших екзотичних куточків світу постають манливими маяками, до яких прагне ліричний герой. Нерідко назви таких привабливих топосів потрапляють у заголовки творів. Так у поезії "Індестанський гімн" [Клен 1992: 223] номінація жанру поєднується із географічною назвою, яка стає проявником мотиву мандрів. Прикметно, що топонім Індостану не лише обрамлює текст - розпочинає його через заголовок $\mathrm{i}$ завершує наприкінці, потрапляючи у сильну позицію. Топонім ще й проходить наскрізно через увесь текст за допомогою такого фонічного прийому як мезостих. Замасковані повтори географічної назви відчитні у таких віршорядках: "табором десь інде стану" (повторюється двічі), "на твердий десь інде стану", "паном я десь інде стану", "Не піду на Інн до стану". Топонім набирає рис звукообразу; мрія про краще життя постає не лише в тексті, а й на його фонічному рівні. Жанрові риси гімну, який номінально заявлений у заголовку поезії, виявляють себе в позірному уславленні нового життя ліричного героя у незвіданих краях. Парадоксальність прославляння не приховується від читача - опоетизовується мрія, а не дійсність (на відміну від норм класичного гімну). Більше того - мрія ліричного героя постає не цілісною, не сформованою остаточно. Про це свідчить зміна топосу, метання героя між манливими куточками Сходу і багатообіцяючими землями Південної та Північної Америк: "Де ж той аргентінський лан, / де оттавські ті майдани? // Може, вирій зацвіте / мені в соняшній Гвіяні <..> $і$ збудую мінарет, / може, в нетрях 
Індостану". Розгубленість, невпевненість ліричного героя підсилюється повтором лексеми "може", уже згадуваної вказівки на невизначеність місця - "десь інде", а також епітетною структурою "незнаному баштані" ("запроваджу рідний рай / на незнаному баштані"). Це свідчить, що урочистий гімн прекрасному майбутньому дещо завчасний, адже ліричний герой стоїть на роздоріжжі і все, у чому він упевнений - це небажання залишатися тут, у дійсності, що його оточує: "Як покину я цей край", "3 мене тут не буде пан", "Не піду на Інн до стану / наших милих земляків". Навіть, здавалося б, досить впевнена і оптимістична теза "Буде там нам дуже добре" викликає сумнів у досить таки іронічному контексті: "бо там справжнє вар'єте: / на деревах павіяни, // жовті леви в чагарях, / довгі гади, хижі кобри. / Хай живе мисливський фах! / Буде там нам дуже добре". Пафос іронічності проймає увесь твір загалом і проступає найбільш показово у таких віршах: "Будуть жирні каплуни / у моєї господині <...> то родзинок ичілий фунт / на бенкет собі дістану. // Родзинками з капшука / буду кури годувати. / Для собаки, для Жука, / постіль постелю із вати". У тексті яскраво проглядається невідповідність низького стилю високому жанрові, який анонсований у заголовкові. Ця невідповідність підкреслює ту прірву, яка розділяє мрію і реальність. Мрія перетворюється на фантом, позбавлений привабливих ідеалістичних рис. Натомість, залишається лише ілюзія кращого, ситого життя. Достеменно не відомо, яким є остаточний топос для мрії; ліричний герой залишається мріяти. I ці мрії віддають гірчинкою, адже натякають на реалії життя українських митців-емігрантів, для яких жодні манливі світи так і не змогли замінити Батьківщину. Жанр гімну в поезії "Індестанський гімн" зазнає травестування і пародіювання.

Схожий мотив мріяння-мандрів звучить у поезії "Елегія собі" [Клен 1992: 213]. Йому вторять мотиви вигнання і смутку за рідною домівкою: "То кличе знов Ітака / голодного, невзутого, / безродного, забутого / вигнания Горотака". Жанрова модель цієї поезії вже більше відповідає анонсованому у заголовкові жанру (елегіï). Проте, визначити взаємозв'язки між текстом і заголовком твору як еквівалентні не дозволяє іронічний пафос твору - ліричний герой наче б то сам кепкує над своїми невдачами. Як слушно зауважує В. Просалова, у збірці "Дияболічні параболи" відбувається не стільки наслідування жанрових канонів, скільки своєрідне 
"пристосування" до них [Просалова 2005: 131]. Таким чином, містифікований автор свідомо не дотримується законів жанру елегії, а лише орієнтується на них. Через несерйозну форму передано серйозний зміст, і саме жанрові риси елегії, що тяжіють над текстом, алюзивно викривають ідейні домінанти.

"Пристосування" до канонів жанру найповніше відбувається в поезіях "Лідійська пісня", "Пияцька пісня", "Архисонет Юрію Кленові", "Острівна баляда", "Ляйтенантська містерія". Наближення до жанрової моделі пісні на формальному рівні здійснюється в поезіях "Лідійська пісня" (Клен 1992, 187), "Пияцька пісня" [Клен 1992: 247]. Творам додають музичності ритмічні повтори всередині віршів ("Hiколи, ніколи, ніколи", "Нікому, нікому, нікому", "буде, буде по мені..."), анафори ("Щоб він лопотів у нестямі, / щоб мій шал затопив береги"), виразні інверсії ("Не на острові я Балі"). Заголовок твору "Архисонет Юрію Кленові" [Клен 1992: 232] містить оказіональну жанрову номінацію ("архисонет") і відсилає читача до творчості Юрія Клена, зокрема до його поезії "Лот". Алюзії досить прозорі - як на семантичному (відсилання до літературних фактів із творчості Юрія Клена), так і на архітектонічному рівні (графічне виділення слова "стовпом" через вертикальне його написання). Застосування формальних ознак сонета в поезії Порфирія Горотака покликане провести паралелі із творчістю Юрія Клена, відтворити стиль поета. Внутрішні, смислові жанрові риси сонета (вибудовування тріади "теза - антитеза синтез") у творі відходять на другий план, що ще раз доводить не стільки застосування жанрової моделі, як пристосування до неї.

Зв’язки заголовка і тексту наближаються до еквівалентності у поетичних творах "Острівна баляда" (Клен 1992, 189) і "Ляйтенантська містерія" [Клен 1992: 249]. Останній із названих творів має підзаголовок "баляда". Дивовижним чином у ньому поєднуються риси як балади, так і містерії: ліро-епічність, напружений, драматичний сюжет, значна роль фантастичних елементів, розгорнена система персонажів. Так само містичністю, таємничістю пройнята "Острівна баляда". Часті риторичні оклики і питання посилюють ліричний струмінь оповіді й драматизм сюжету. Привертає увагу наративна композиція поетичного твору - оповідь організована у формі діалогу двох закоханих. Причому в дівочому образі вгадується (але не назива- 
ється прямо) істота містична (можливо русалка, сирена чи й сама Діва Рейну - Лорелея). Архетипний образ таємничої діви, романтичний пафос, а також вказівка на жанр у заголовкові актуалізують інтертекстуальне поле твору, роблять проекцію на творчі здобутки німецьких романтиків.

Отже, взаємозв'язки між заголовковим комплексом і текстами збірки "Дияболічні параболи" Порфирія Горотака тісно поєднані із жанровим аспектом. Номінація жанрів у заголовках впливає на формування читацького горизонту очікувань, орієнтує реципієнта на певну жанрову модель. Однак, саме явище літературної містифікації робить ідейно-змістовий пласт збірки Порфирія Горотака неоднозначним. Назва кожного твору продовжує гру з читачем, призводить до обману його очікувань. Між анонсованим у заголовкові жанром і жанровими рисами твору виникають складні зв'язки, серед яких можна виокремити три тенденції: травестування жанру, "пристосування" до канонів жанру і взаємозв'язки, що наближаються до еквівалентності. Переважно номінація жанру у заголовкові створює жанровий симулякр, заснований на прийомі травестування жанру, перелицюванні його основних рис, пародіюванні. Разом із тим, травестована жанрова модель твору зберігає окремі риси класичного жанрового канону (спрацьовує "пам'ять жанру"). Зіштовхування прийому травестування і наслідування жанру створює ефект несподіванки й одивнення, що спонукає читача заглибитися у підтекст твору. Через іронічний пафос і застосування елементів низького стилю у творах з ознаками "високих" жанрів втілюється прийом "пристосування" до канонів жанру. Зв'язки еквівалентності між заголовком, що містить номінацію жанру, і текстом - явище рідкісне. Це пояснюється приналежністю текстів збірки до літературної містифікації, яка сприяє смисловій багатошаровості і неоднозначності.

\section{ЛITЕРАТУРА}

Арнольд, И. Значение сильной позиции для интерпретащии художественного текcma. «Иностранные языки в школе», 1978, № 4, с. 23-31.

Біляшевич, Р. Поліфонічні форми в українській художній літературі першої половини $X X \mathrm{~cm}$. «Наукові записки Тернопільського національного педагогічного університету імені Володимира Гнатюка. Сер. Літературознавство», 2013, вип. 38, c. $266-275$. 
Блисковский, 3. Муки заголовка, Москва, 1972.

Грицюк, Л. Образно-семантичний підхід до класифікаиії заголовків, «Мовознавство» 1992, № 2, с. 51-56.

Иванова, О. Структура полифонической композиции и ее реализащия в художественном тексте, «Вестник КемГУКИ. Культурология», 2016, вып. 36, с. 108-114.

Иванова, С. Языковые особенности поэтического заголовка (на материале русского и английского языков): автореф. дис. ... канд. филол. наук, Ульяновск 2006.

Клен Ю. Твори: у 4-х т. Т. 1. Нью-Йорк 1992.

Кожина Н. Заглавие художественного произведения: онтология, функции, параметры типологии, в: Проблемы структурной лингвистики: сб. научн. Трудов, Москва 1988, с. 167-183.

Кржижановский, С. Пьеса и ее заглавие. «Новое литературное обозрение: Теория и история литературы, критика и библиография», 2001, № 52, с. 207-208.

Мержвинський, В. Поетика заголовків драматичних творів Лесі Українки. «Слово і час», 2007, № 2, с. 32-40.

Просалова, В. Текст у світі текстів Празької літературної школи: монографія. Донецьк 2005.

Рижкова, С. Роль та функиії заголовку в художніх творах (на матеріалі англійської та німецької художньої літератури), «Науковий вісник Міжнародного гуманітарного університету. Сер. Філологія», 2014, № 10, т. 2, с. 38-40.

Шкарлута, Т. Містифікація "Порфирій Горотак" в еміграційному літературному процесі 1940-х років. Дис. ... канд. філол. Наук, Київ 2016. 